\title{
The Influence of the City of Przemyśl on the Quality of Water in the San River
}

\author{
Jadwiga Kaleta ${ }^{1 *}$, Alicja Puszkarewicz' ${ }^{1}$, Dorota Papciak \\ 1 Rzeszów University of Technology, The Faculty of Civil and Environment Engineering and Architecture, \\ Department of Water Purification and Protection, ul. Poznańska2, 35-084 Rzeszów, Poland \\ * Corresponding author's e-mail: jkaleta@prz.edu.pl
}

\begin{abstract}
The purpose of this paper was to assess the influence of the city of Przemyśl on the quality of water in the San River. The water analysis carried out by the Voivodeship Environmental Protection Inspector in Rzeszów as part of the operational monitoring in 2014 and in 2017 was used in the study. The concentrations of selected physicochemical indicators determined in two measurement and control points located above and below the city of Przemyśl were taken into account. For each water quality indicator, the minimum and maximum values were determined and the arithmetic averages from the research period were calculated. In addition, the regularly performed indicators were subjected to a detailed statistical analysis. Box plot graphs show the extreme values, the median and the interquartile range. Water quality has been assigned to the appropriate class and category of surface waters. Selected specific pollutants and priority substances in the river water were also analysed. Only the concentration of benzo(a) pyrene at the measuring points did not comply with the environmental quality standards. It was found that the city of Przemyśl has a small influence on the quality of water in the San River. Although there was a deterioration of water quality at the measurement and control point below the city, its class and category did not change.
\end{abstract}

Keywords: water, ecological status, region of Przemyśl, quality indications

\section{INTRODUCTION}

Pollution of natural waters is a common phenomenon and its main cause is the presence of various substances in water that may come from natural or artificial sources [Policht-Latawiec et al. 2014]. Progressive economic development, especially in various branches of industry, has a negative impact on the environment [Grzywna et al. 2016]. The surface waters are the most susceptible to pollution [Kalda and Miętus 2016]. The pollutants entering rivers, lakes or streams can have different sources: area, point and line. Agriculture is also a serious source of surface water pollution. Biogenic compounds flowing into waters are the cause of eutrophication [NeverowaDziopak and Kowalewski 2013, Kaniuczak and Augustyn 2011, Kiryluk and Rauba 2011]. Organic compounds found in surface waters hinder the treatment for water supply purposes [Pietrzyk and Papciak 2016]. In addition, a threat to the quality of surface waters is associated with significant water abstraction for municipal and industrial purposes.

Water Framework Directive [Directive 2000] imposed the obligation to achieve and maintain a good ecological status for all surface and ground waters by 2015 on all Member States. In order to meet the requirements of the Water Framework Directive (RWD), a five-stage division of surface waters in terms of quality was developed in Poland; for the first time in 2011, then in 2014, and the latest version is from 2016 [Regulation 2016 B]. In addition, in order to establish the treatment technology, the waters taken for supplying the population are divided into three categories: A1, A2 and A3 [Regulation 2002].

Water monitoring carried out in the Podkarpackie Voivodeship showed that the primary objective of WFD was not achieved in the majority of uniformed water bodies, mainly due to the occurrence of eutrophication, caused by the emis- 
sion of sewage from municipal sources. Water pollution in the region is additionally aggravated by the sewage discharged from unidentified point sources as well as from urban and agricultural area sources. In the Podkarpackie Voivodeship, the most polluted rivers are: San, Wisłoka and Wisłok [Policht-Latawiec et al. 2013, Report 2016].

The purpose of this paper was to assess the influence of the city of Przemyśl on the quality of water in the San River. This influence was assessed on the basis of the concentrations of selected physical and chemical indicators defined in two measurement and control points located above and below the city of Przemyśl in 2014 and in 2017.

\section{MATERIAL AND METHODS}

The city of Przemyśl is located in southeastern Poland (Podkarpackie voivodeship) on the San River at the mouth of the Wiar River. According to the data from the Central Statistical Office of 2017, the city's population is 62,154 , its area is $46 \mathrm{~km}^{2}$ and the population density is 1,346 people $/ \mathrm{km}^{2}$. The following branches of industry operate in the city: wood („Fibris” - fiberboard manufacturer), mechanical and industrial automation (Polna, Fanina), cosmetics (Inglot), coated fabrics (Sanwil) and the manufacturer of paints and school aids - Pollena Astra.

San is one of the largest and most water-rich Carpathian rivers, which is of great economic importance for the Podkarpackie voivodeship. The river flows out in the Western Bieszczady Mountains at an altitude of around $900 \mathrm{~m}$ above sea level, in Ukraine. The length of the San River is 457.76 $\mathrm{km}$, and the catchment area is $16,861 \mathrm{~km}^{2}$. On the section of $54 \mathrm{~km}$, it is a border river between Poland and Ukraine. San is a right-bank tributary of the Vistula River and is considered one of the most beautiful rivers in Poland. In its upper course up to Przemyśl, it is a mountain river, while below Przemyśl it has the characteristics of a lowland river. Upper San and its tributaries collect water from areas under legal protection due to high natural and landscape values [Association 214].

The subject of the research included the physical and chemical analyses carried out as part of operational monitoring (repeated every 3 years) by the Voivodeship Environmental Protection Inspector in Rzeszów in 2014 and 2017 [Regulation $2016 \mathrm{~A}$ ].
The results of the State Environmental Monitoring (SEM) have been made available in accordance with the provisions of the Act of 3 October 2008 on access to information about the environment and its protection, public participation in environmental protection and environmental impact assessments (Journal of Laws 2008 No. 199 item 1227) by the Voivodeship Environmental Protection Inspector in Rzeszów with the delegation in Przemyśl.

In order to assess the influence of the city of Przemyśl on the San River, an analysis of the results of measurements obtained from the measurement and control points (mcp) of the central course of the San River was conducted, i.e.: mcp of San - Krasice (above the city - Zmn1) and mcp of San - Hureczko (below the city - Zmn2). These points are $30.4 \mathrm{~km}$ apart. They were covered by the monitoring of protected areas.

According to the typology used by SEM at the San - Krasice point, the river in question is referred to as type no. 15 , i.e. the high - eastern medium river, while at the measurement and control point behind the city of Przemyśl, type no. 19 (lowland sandy-clayey river) [Report 2016]. The influence on changing the abiotic type of San is due to the existence of a water level damming the river. Physical indicators, aerobic conditions, indicators of organic pollution, salinity indices, acidification, share of nutrients and specific synthetic and non-synthetic substances and priority substances were taken into account in the analysis. The water quality was assigned to the appropriate class [Regulation 2016 B] and category [Regulation 2002].

In 2016, significant legal changes occurred in the area of surface water status assessment introduced by the amended Regulation [Regulation $2016 \mathrm{~B}$ ]; that is why the number of markings made in 2017 was higher than in 2014.

For each water quality indicator, the minimum and maximum values were determined and the arithmetic averages from the research period were calculated. In addition, the indicators that were performed regularly were subjected to detailed statistical analysis. Box plot graphs show the extreme values, the median and the interquartile range.

\section{RESULTS}

The scope of changes, average and median values, as well as the assignment to the water 
quality class and the category of selected physical, oxygen, salinity and biogenic indicators are presented in Table 1.

The temperature of the water in the mcp of Krasice in all research dates was lower than $22^{\circ} \mathrm{C}$, but in the mcp of Hureczko, it exceeded this value twice, equalling to 23.8 and $23.9^{\circ} \mathrm{C}$. While the average values amounted to $10.83^{\circ} \mathrm{C}$ and $11.68^{\circ} \mathrm{C}$ and based on them the water was classified as first class purity and category A1.

The colour of the water made in the mcp of Krasice allows to assign the water to the A1 category. In contrast, in the mcp of Hureczko, only one result exceeded the value of 20 $\mathrm{mgPt} \cdot \mathrm{dm}^{-3}$, but taking into account the average value of $12 \mathrm{mgPt} \cdot \mathrm{dm}^{-3}$, the water was also assigned to the category $\mathrm{A} 1$.

Concentrations of dissolved oxygen, with the exception of a single measurement in mcp of Krasice of $6.6 \mathrm{mgO}_{2} \cdot \mathrm{dm}^{-3}$, exceeded the value of $7.0 \mathrm{mgO}_{2} \cdot \mathrm{dm}^{-3}$, that is, they met the requirements for class I of ecological status.

In the case of biochemical oxygen demand $\left(\mathrm{BOD}_{5}\right)$, the maximum values in both mcps exceeded $3.0 \mathrm{mgO}_{2} \cdot \mathrm{dm}^{-3}$, but on the basis of average values of $1.665 \mathrm{mgO}_{2} \cdot \mathrm{dm}^{-3}$ (above the city) and $2.005 \mathrm{mgO}_{2} \cdot \mathrm{dm}^{-3}$ (below the city), the water was classified in the first class of purity and in the A1 category. However, it can be noticed that the average value of oxygen demand was significantly higher (by $17.5 \%$ ) below the city of Przemyśl. At this point, there are also two values that stand out from the other results.

The total organic carbon (TOC) was more unfavourable at the point above the city (average value of $3.889 \mathrm{mgC} \cdot \mathrm{dm}^{-3}$ ) and on this basis, this section of the river was assigned to the $2^{\text {nd }}$ class. Despite the fact that the TOC index values below the city were higher (average value of $4.566 \mathrm{mgC} \cdot \mathrm{dm}^{-3}$ ), due to the change of the abiotic type, the river on this section can be classified in the first class of purity. Extreme values were noted for this indicator; in mcp of Krasice Krasice in July 2014, it was $11.6 \mathrm{mgC} \cdot \mathrm{dm}^{-3}$, while in mcp of Hureczko in March 2017, the value of TOC increased to $12.5 \mathrm{mgC} \cdot \mathrm{dm}^{-3}$. Taking into account the average values of TOC, the water in the analyzed mcp has a category A1.

The values of electrolytic conductivity and general hardness at the point above the city of Przemyśl were at a low level in relation to the limit value for the first class of purity and category A1. Significantly higher values, but not affecting the change of the water class and cat-

Table 1. Physicochemical indicators in the water of the San River above (Zmn1- Krasice) and below (Zmn2- Hureczko) in the city of Przemyśl in 2014-2017

\begin{tabular}{|c|c|c|c|c|c|c|c|}
\hline \multirow{2}{*}{ Indicator } & \multirow{2}{*}{ Unit } & \multicolumn{2}{|c|}{ Range of changes } & \multicolumn{2}{|c|}{ Average (median) } & \multicolumn{2}{|c|}{$\begin{array}{c}\text { Quality class } \\
\text { (category) }\end{array}$} \\
\hline & & Zmn1 & Zmn2 & Zmn1 & $\mathrm{Zmn} 2$ & Zmn1 & Zmn2 \\
\hline \multicolumn{8}{|c|}{ Physical indicators } \\
\hline Temperature & ${ }^{\circ} \mathrm{C}$ & $0.1-22.0$ & $0.1-23.9$ & $10.83(10.4)$ & $\begin{array}{l}11.675 \\
(10.6)\end{array}$ & $\mathrm{I}(\mathrm{A} 1)$ & $\mathrm{I}(\mathrm{A} 1)$ \\
\hline Color & $\mathrm{mgPt} \cdot \mathrm{dm}^{-3}$ & $6-15$ & $6-25$ & $10.125(10)$ & $12.875(12)$ & (A1) & (A1) \\
\hline \multicolumn{8}{|c|}{ Oxygen indicators } \\
\hline Dissolved oxygen & $\mathrm{mgO}_{2} \cdot \mathrm{dm}^{-3}$ & $6.6-15$ & $7.1-14.8$ & $\begin{array}{l}10.6833 \\
(10.65)\end{array}$ & $10.33(9.75)$ & I & I \\
\hline $\mathrm{BOD}_{5}$ & $\mathrm{mgO}_{2} \cdot \mathrm{dm}^{-3}$ & $1.1-3.2$ & $0.6-4.4$ & $1.665(1.65)$ & $2.005(2)$ & $\mathrm{I}(\mathrm{A} 1)$ & $\mathrm{I}(\mathrm{A} 1)$ \\
\hline TOC & $\mathrm{mgC} \cdot \mathrm{dm}^{-3}$ & $2.3-11.6$ & $3.0-12.5$ & $\begin{array}{c}3.88933 \\
(3.6) \\
\end{array}$ & $\begin{array}{c}4.56643 \\
(3.83) \\
\end{array}$ & II(A1) & $\mathrm{I}(\mathrm{A} 1)$ \\
\hline \multicolumn{8}{|c|}{ Salinity indicators } \\
\hline Conductivity at $20^{\circ} \mathrm{C}$ & $\mu S \cdot \mathrm{cm}^{-1}$ & $248-390$ & $271-607$ & $306.45(307)$ & $\begin{array}{l}363.45 \\
(349.5)\end{array}$ & $\mathrm{I}(\mathrm{A} 1)$ & $\mathrm{I}(\mathrm{A} 1)$ \\
\hline General hardness & $\mathrm{mgCaCO}_{3} \cdot \mathrm{dm}^{-3}$ & $140-202$ & $152-290$ & $166.1(162)$ & $\begin{array}{c}195.3 \\
(190.5)\end{array}$ & I & I \\
\hline Reaction & $\mathrm{pH}$ & $7.7-8.4$ & $7.4-8.4$ & $8.13(8.2)$ & $7.995(8)$ & $\mathrm{I}(\mathrm{A} 1)$ & $\mathrm{I}(\mathrm{A} 1)$ \\
\hline \multicolumn{8}{|c|}{ Biogenic compounds } \\
\hline Ammonium nitrogen & $\mathrm{mgN}-\mathrm{NH}_{4}^{+} \cdot \mathrm{dm}^{-3}$ & $<0.05-0.106$ & $<0.05-0.78$ & $0.053(0.05)$ & $0.089(0.05)$ & $\mathrm{I}(\mathrm{A} 1)$ & $\mathrm{I}(\mathrm{A} 1)$ \\
\hline Nitrate nitrogen & $\mathrm{mgN}-\mathrm{NO}_{3}^{-\cdot} \cdot \mathrm{dm}^{-3}$ & $0.026-0.66$ & $0.026-3.7$ & $\begin{array}{c}0.3634 \\
(0.42) \\
\end{array}$ & $\begin{array}{c}0.58396 \\
(0.435) \\
\end{array}$ & $>\operatorname{II}(\mathrm{A} 1)$ & $>\operatorname{ll}(\mathrm{A} 1)$ \\
\hline General nitrogen & $\mathrm{mgN} \cdot \mathrm{dm}^{-3}$ & $<0.3-1.4$ & $<0.3-4.29$ & $\begin{array}{c}0.8855 \\
(0.92)\end{array}$ & $\begin{array}{c}1.21583 \\
(1.13)\end{array}$ & I & I \\
\hline Phosphates & $\mathrm{mgPO}_{4}{ }^{3-\cdot} \cdot \mathrm{dm}^{-3}$ & $<0.05-<0.05$ & $<0.05-0.263$ & $\begin{array}{c}<0.05 \\
(0.005)\end{array}$ & $0.064(0.05)$ & $\mathrm{I}(\mathrm{A} 1)$ & $\mathrm{I}(\mathrm{A} 1)$ \\
\hline General phosphorus & $\mathrm{mgP} \cdot \mathrm{dm}^{-3}$ & $<0.05-0.13$ & $<0.05-0.0978$ & $\begin{array}{c}0.04975 \\
(0.05) \\
\end{array}$ & $\begin{array}{c}0.059938 \\
(0.05) \\
\end{array}$ & I & I \\
\hline
\end{tabular}


egory were noted below the city, which proves the influence of urban areas on the salinity of waters. At the point below the city, an extreme value for the conductivity of $607 \mu \mathrm{S} \cdot \mathrm{cm}^{-1}$.was noted, and the total hardness twice had values that exceeded $250 \mathrm{mgCaCO}_{3} \cdot \mathrm{dm}^{-3}$.

On the basis of the range of the extreme $\mathrm{pH}$ values, $7.7-8.4$ (above the city) and $7.4-8.4$ (below the city) - it can be assumed that the tested waters had a neutral to slightly alkaline $\mathrm{pH}$. The average values of this indicator were slightly lower at the point below the city, but in both cases they met the requirements of very good ecological status and had the A1 category.

The average concentrations of all analysed biogenic compounds below the city ( $\mathrm{Zmn} 2)$ were greater than those recorded in the point above (Zmn1). In the case of ammonium nitrogen, these values were very low, $80 \%$ below $0.05 \mathrm{mg}$ $\mathrm{N}-\mathrm{NH}_{4}^{+} \cdot \mathrm{dm}^{-3}$. The measurement made in January 2017 , where the concentration of ammonium nitrogen was $0.106 \mathrm{mgN}-\mathrm{NH}_{4}^{+} \cdot \mathrm{dm}^{-3}$ (above the city) and $0.78 \mathrm{mgN}-\mathrm{NH}_{4}^{+} \cdot \mathrm{dm}^{-3}$ (below the city), respectively, constituted an exception. The nitrate nitrogen values varied within wide limits; from trace amounts of $0.026 \mathrm{mg} \mathrm{N}-\mathrm{NO}_{3} \cdot \mathrm{dm}^{-3}$ to $3.7 \mathrm{mg}$ $\mathrm{N}-\mathrm{NO}_{3} \cdot \mathrm{dm}^{-3}$. Due to the average values of this indicator, the San River water, both above and below the city, has a status lower than good; however, it falls into the A1 category. The average values of total nitrogen were $0.92 \mathrm{mgN} \cdot \mathrm{dm}^{-3}$ (above the city) and $1.13 \mathrm{mgN} \cdot \mathrm{dm}^{-3}$ (below the city). However, there were outliers in both points: 2.1 $\mathrm{mgN} \cdot \mathrm{dm}^{-3}$. (point Zmn1 - September 2014) and $4.29 \mathrm{mgN} \cdot \mathrm{dm}^{-3}$ (point Zmn2 - December 2017). Phosphates in mcp Zmn1 assumed the values $<0.05 \mathrm{mgPO}_{4}^{3-\cdot} \cdot \mathrm{dm}^{-3}$, whereas in mcp Zmn2, only in January 2014 and 2017 they occurred in higher concentrations of $0.263 \mathrm{mgPO}_{4}^{3-\cdot} \mathrm{dm}^{-3}$ and 0.132 $\mathrm{mgPO}_{4}{ }^{3-\cdot} \cdot \mathrm{dm}^{-3}$, respectively. The concentrations of total phosphorus as well as phosphates were low; the exception was a single measurement in the month of March 2017 at the point above the city, where the value of $0.13 \mathrm{mgP} / \mathrm{dm}^{3}$ was recorded. Despite the differences between the measurement points, the water in both cases had a very good ecological status, because the average values of ammonium nitrogen, total nitrogen, phosphates and total phosphorus did not exceed the first class standards and limit values for category A1.

Selected specific synthetic and non-synthetic impurities as well as priority substances are listed in Table 2. Their analysis enabled to qualify the water of the San River both above and below the city to the first class of quality, that is, to a very good condition and to the A1 category. The only exception is the representative of polycyclic aromatic hydrocarbons (PAHs) which is benzo(a) pyrene. In both measuring points, this indicator classifies San waters below the good status. The occurrence of PAHs in the upper catchment of the San River is a phenomenon characteristic of these areas and is associated with the occurrence of oil deposits. One can also notice the negative influence of the city, because in the mcp - Hureczko the concentration of benzo(a)pyrene was 2.5 times higher than in mcp - Krasice.

Obtained results of tests in the field of physical, oxygen, salinity and biogenic indicators were subjected to a statistical analysis and illustrated on the box plot graphs (Figures 1, 2, 3, 4). In the scope of all the above-mentioned indicators, mcp - Hureczko (Zmn2) was the worst point. These differences were not significant, but point at the negative influence of the city on the quality of the San River.

\section{CONCLUSION}

The San river water above and below the city of Przemyśl meets the requirements of very good ecological status ( $1^{\text {st }}$ class of purity) in the scope of the majority of analysed physical and chemical indicators. Nitrate nitrogen is the exception. Due to this parameter, the water quality of the San River is below the good status. The main source of nitrates could be surface runoffs from areas located above the city of Przemyśl, which are used for agriculture and inflow of sewage from point sources both from the municipal sewage treatment plant as well as from untreated sewage from unidentified sources. Additionally, the TOC indicator at the point above the city qualifies the water of the river to the $2^{\text {nd }}$ class of purity.

The values of the analysed indicators allow to qualify San waters in both measurement points to the A1 category, i.e. water requiring simple physical treatment, in particular filtration and disinfection in order to obtain water suitable for human consumption.

Among the analysed indicators of specific and priority pollutants, only the concentration of benzo(a)pyrene in the measurement points did not comply with environmental quality standards. 
Table 2. Selected specific pollutants and priority substances in the water of the San River above (Zmn1- Krasice) and below (Zmn2- Hureczko) in the city of Przemyśl in the years $2014-2017$

\begin{tabular}{|c|c|c|c|c|c|c|c|}
\hline \multirow{2}{*}{ Indicator } & \multirow{2}{*}{ Unit } & \multicolumn{2}{|c|}{ Range of changes } & \multicolumn{2}{|c|}{ Average } & \multicolumn{2}{|c|}{ Quality class (category) } \\
\hline & & Zmn1 & Zmn2 & Zmn1 & Zmn2 & Zmn1 & Zmn2 \\
\hline \multicolumn{8}{|c|}{ Specific synthetic and non-synthetic pollutants } \\
\hline General chrome & $\mathrm{mgCr} \cdot \mathrm{dm}^{-3}$ & $<0.005$ & $<0.005$ & $<0.005$ & $<0.005$ & $\mathrm{I}(\mathrm{A} 1)$ & $(\mathrm{A} 1) !$ \\
\hline Zinc & $\mathrm{mgZn} \cdot \mathrm{dm}^{-3}$ & $<0.05^{+} \mathrm{i}<0.01^{*}$ & $\begin{array}{l}<0.05^{+} \\
\mathrm{i}<0.01^{*}\end{array}$ & $\begin{array}{l}<0.05+ \\
\mathrm{i}<0.01^{*}\end{array}$ & $<0.05+\mathrm{i}<0.01^{*}$ & $\mathrm{I}(\mathrm{A} 1)$ & $\mathrm{I}(\mathrm{A} 1)$ \\
\hline Copper & $\mathrm{mgCu} \cdot \mathrm{dm}^{-3}$ & $<0.005$ & $<0.005$ & $<0.005$ & $<0.005$ & $\mathrm{I}(\mathrm{A} 1)$ & $\mathrm{I}(\mathrm{A} 1)$ \\
\hline Volatile phenols & $\mathrm{mg} \cdot \mathrm{dm}^{-3}$ & $<0.002$ & $<0.002$ & $<0.002$ & $<0.002$ & $\mathrm{I}(\mathrm{A} 1)$ & $\mathrm{I}(\mathrm{A} 1)$ \\
\hline $\begin{array}{l}\text { Petroleum } \\
\text { hydrocarbons (oil } \\
\text { index) }\end{array}$ & $\mathrm{mg} \cdot \mathrm{dm}^{-3}$ & $<0.05$ & $<0.05$ & $<0.05$ & $<0.05$ & I & I \\
\hline Cyanide free & $\mathrm{mg} \cdot \mathrm{dm}^{-3}$ & $\begin{array}{l}<0.003- \\
0.0052\end{array}$ & $\begin{array}{l}<0.003- \\
<0.005\end{array}$ & $\begin{array}{c}<0.003- \\
0.0052\end{array}$ & $<0.003-<0.005$ & I(A1) & I(A1) \\
\hline \multicolumn{8}{|c|}{ Priority substances } \\
\hline Anthracene & $\mu \mathrm{g} \cdot \mathrm{dm}^{-3}$ & $\begin{array}{c}<0.001- \\
0.0023\end{array}$ & $\begin{array}{c}<0.001- \\
0.0045\end{array}$ & 0.00119 & 0.00145 & I & I \\
\hline Benzene & $\mu \mathrm{g} \cdot \mathrm{dm}^{-3}$ & $<0.1$ & $<0.1$ & $<0.1$ & $<0.1$ & 1 & 1 \\
\hline $\begin{array}{l}\text { Cadmium and its } \\
\text { connections }\end{array}$ & $\mu \mathrm{g} \cdot \mathrm{dm}^{-3}$ & $<0.15$ & $<0.15$ & $<0.15$ & $<0.15$ & $\mathrm{I}(\mathrm{A} 1)$ & $\mathrm{I}(\mathrm{A} 1)$ \\
\hline $\begin{array}{l}\text { Lead and its } \\
\text { compounds }\end{array}$ & $\mu \mathrm{g} \cdot \mathrm{dm}^{-3}$ & $<2.0^{+} \mathrm{i}<1.2^{*}$ & $<2.0^{+} \mathrm{i}<1.2^{*}$ & $\begin{array}{l}<2.0^{+} \mathrm{i} \\
<1.2^{*}\end{array}$ & $<2.0^{+} \mathrm{i}<1.2^{*}$ & I(A1) & I(A1) \\
\hline $\begin{array}{l}\text { Mercury and its } \\
\text { compounds }\end{array}$ & $\mu \mathrm{g} \cdot \mathrm{dm}^{-3}$ & $<0.01-0.053$ & $<0.01-0.038$ & 0.0182 & 0.0136 & $\mathrm{I}(\mathrm{A} 1)$ & $\mathrm{I}(\mathrm{A} 1)$ \\
\hline Nickel & $\mu \mathrm{g} \cdot \mathrm{dm}^{-3}$ & $<5^{+} \mathrm{i}<4^{*}$ & $<5^{+} \mathrm{i}<4^{*}$ & $<5+\mathrm{i}<4^{*}$ & $<5+\mathrm{i}<4^{*}$ & $\mathrm{I}(\mathrm{A} 1)$ & $\mathrm{I}(\mathrm{A} 1)$ \\
\hline Benzo (a) pyrene & $\mu \mathrm{g} \cdot \mathrm{dm}^{-3}$ & $\begin{array}{c}0.00023- \\
0.0019\end{array}$ & $\begin{array}{c}0.00045- \\
0.0140\end{array}$ & 0.00173 & 0.00801 & $\begin{array}{c}\text { Below } \\
\text { good (A1) }\end{array}$ & $\begin{array}{l}\text { Below good } \\
\text { (A1) }\end{array}$ \\
\hline
\end{tabular}

+ 2014 year

* 2017 year

The city of Przemyśl has a small influence on the quality of water in the San River. Although there was a deterioration of water quality in the majority of analysed indicators at the measurement and control point below the city, its class and category did not change.
In order to improve the quality of the San River water, it is necessary to expand the sewerage network in the areas recently connected to the city of Przemyśl and to expand the rainwater sewage system in the city in order to manage rainwater and snowmelt.
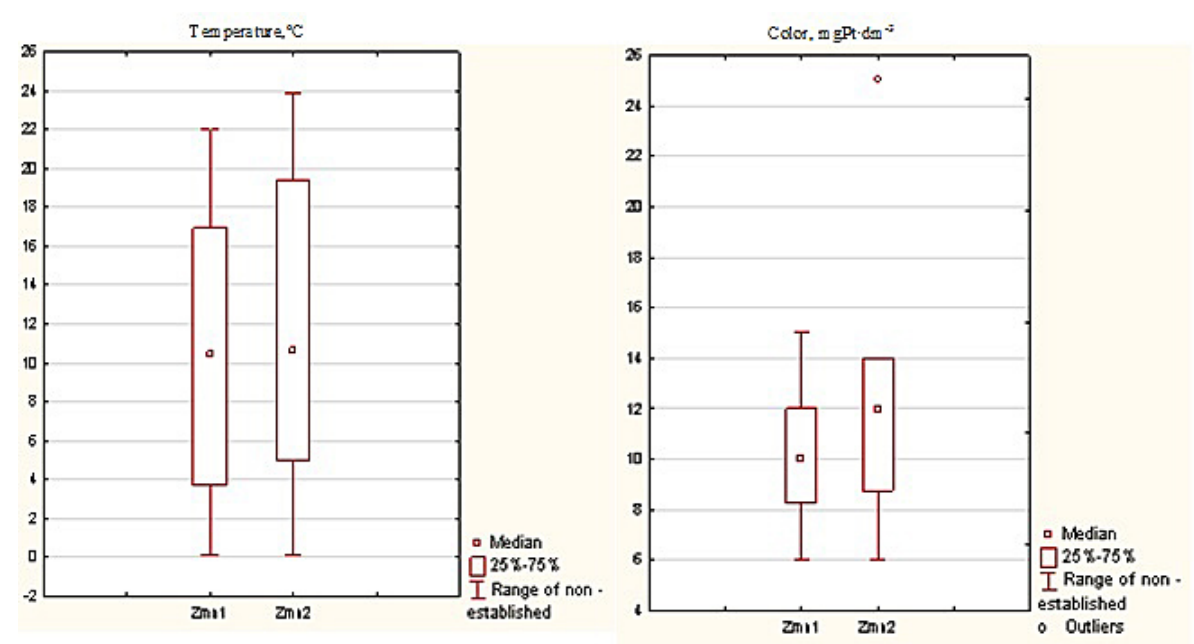

Figure 1. Extreme values, median and quartile distribution of physical indicators, Zmn1 - Krasice, Zmn2 - Hureczk 

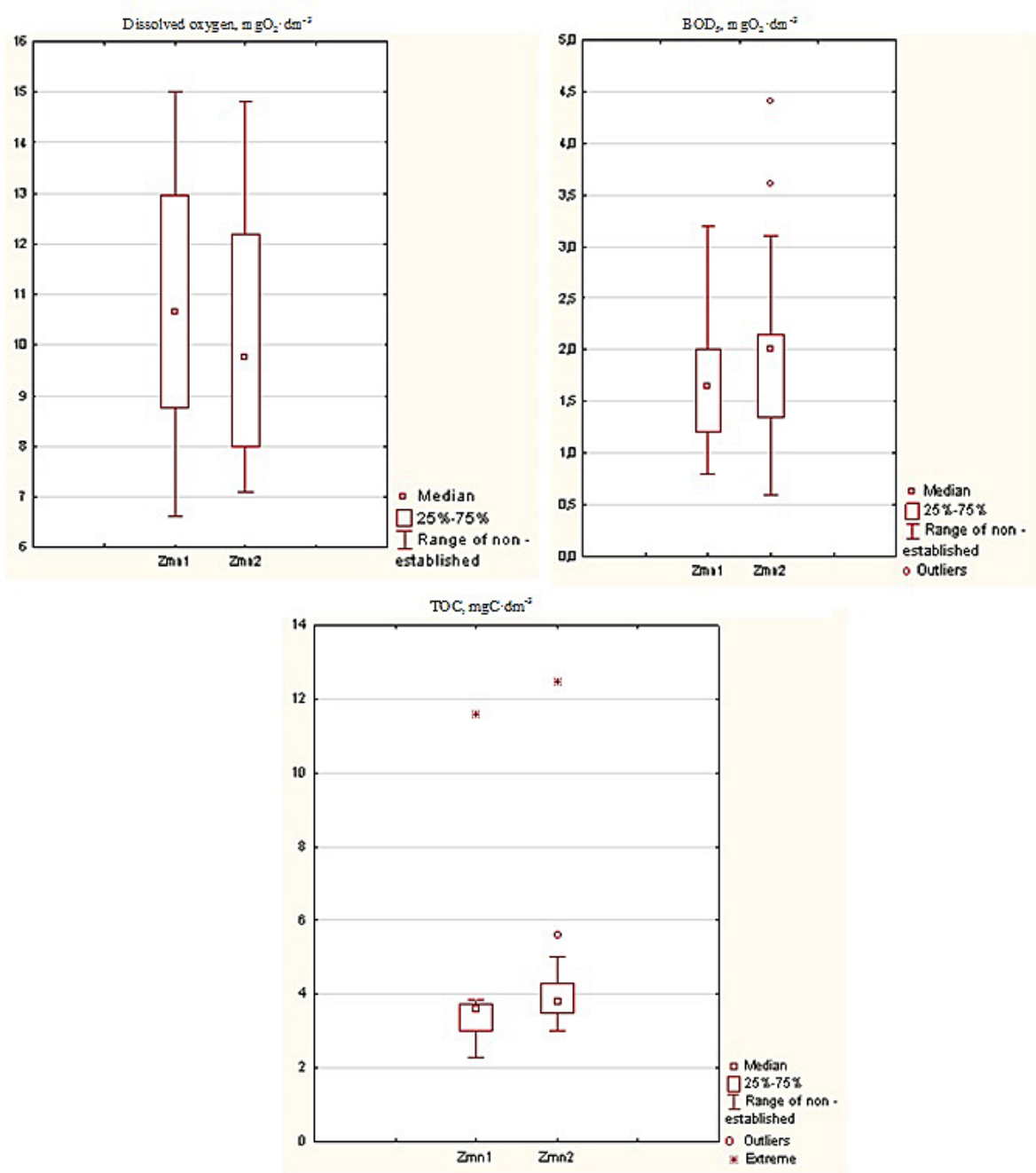

Figure 2. Extreme values, median and quartile distribution of oxygen indicators, Zmn1 - Krasice, Zmn2 - Hureczko
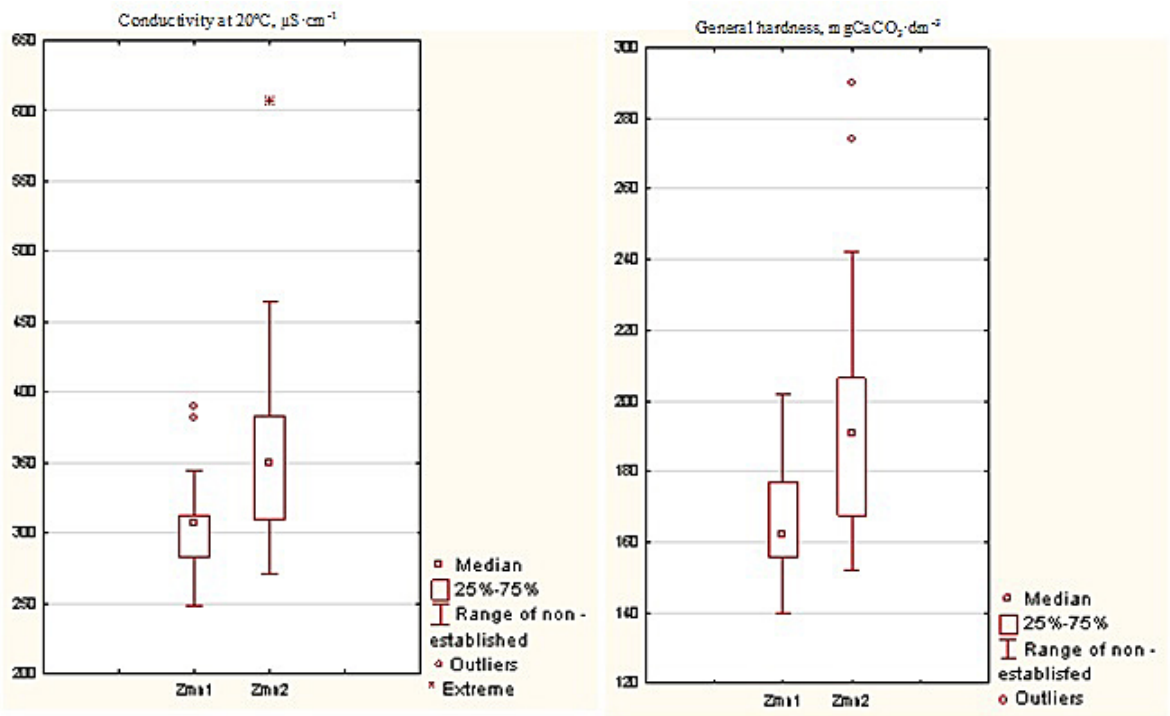

Figure 3. Extreme values, median and quartile distribution of salinity indices, Zmn1 - Krasice, Zmn2 - Hureczko 


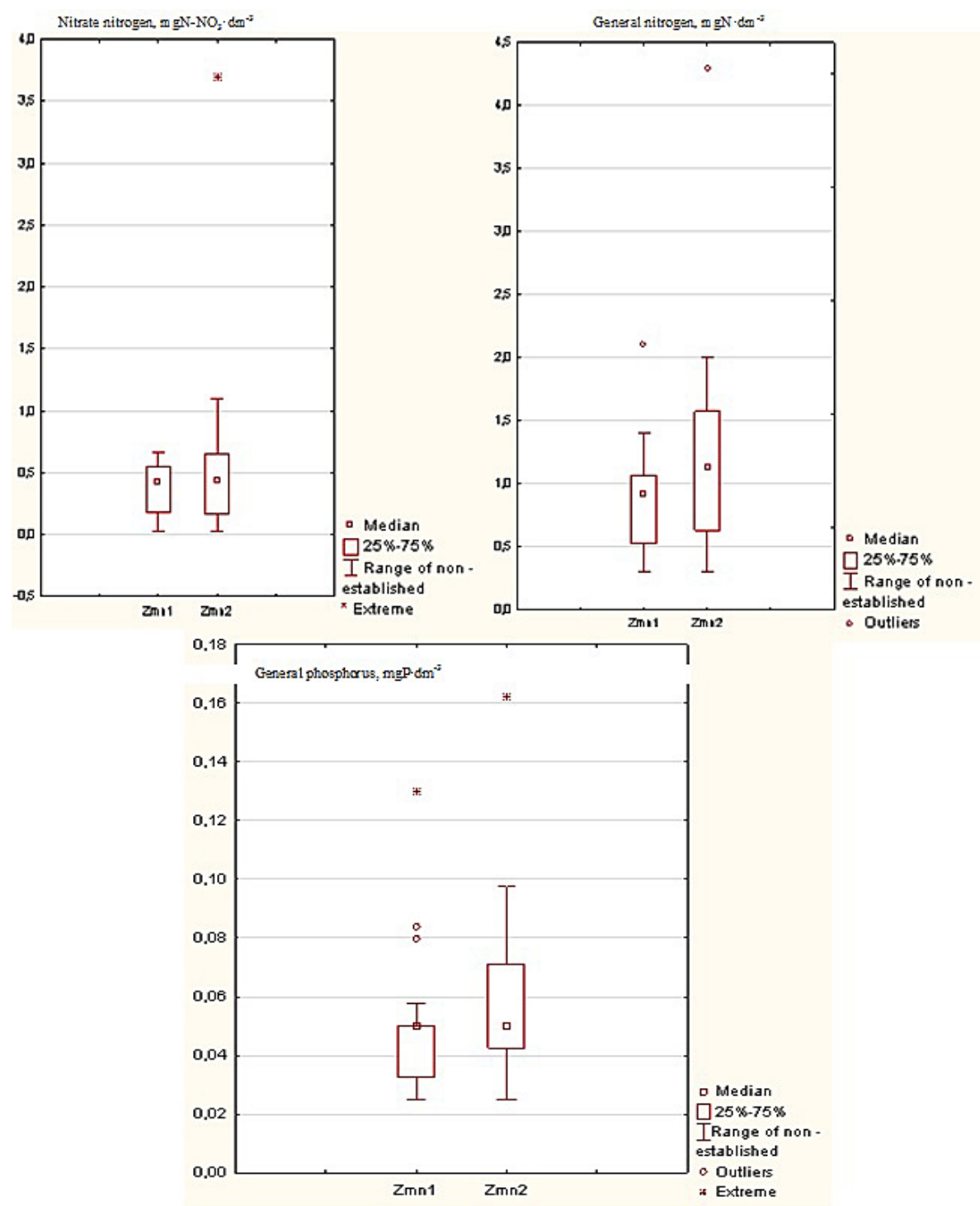

Figure 4. Extreme values, median and quartile distribution of biogenic compounds, Zmn1 - Krasice, Zmn2 - Hureczko

\section{REFERENCES}

1. Association of Tourist Municipalities Pomer Dynowski. 2014. Over the Blue San. Quercus publishing house. Dynów.

2. Directive 2000/60/EC of the European Parliament and of the Council establishing a framework for Community action in the field of water police. OJ L 327, 21.12.2000.

3. Galina Kalda G., Miętus I. 2016. Environmental protection in tourism in Podkarpacie. Journal of Civil Engineering, Environment and Architecture JCEEA, Vol.. XXXIII, No. 63 (2/I/16), pp. 65 - 75.

4. Grzywna A., Jóźwiakowski K., Gizińska-Górna M., Marzec M., Mazur A., Obroślak R. 2016. Analysis of ecological status of surface waters in the Bystrzyca river in Lublin. Journal of Ecological Engineering, Vol. 17, Issue 5, pp. 203-207.
5. Kaniuczak J., Augustyn Ł. 2011. The content of nitrogen compounds and phosphates in surface water intended for supply in drinking water. Ecological Engineering, 27, 46-59.

6. Kiryluk A., Rauba M. 2011. Impact of agriculture on the concentration of total phosphorus in the surface water catchment area Ślina. Ecological Engineering, 26, 122-132.

7. Neverowa-Dziopak E., Kowalewski Z. 2013. Dynamics of eutrophication process development in the rivers of Subcarpathian Voivodeship. Journal of Civil Engineering, Environment and Architecture JCEEA, Vol. XXX, No. 60 (3/13), pp. 47-59.

8. Pietrzyk A., Papaciak D. 2016. Organic matter in natural water - forms and method for determining. Journal of Civil Engineering, Environment and Architecture JCEEA Vol. XXXIII, No. 63 (2/I/16), pp. 241-253. 
9. Policht-Latawiec A., Bogdał A., Kanownik W., Kowalik T., Ostrowski K., Gryboś P. 2014. Quality and usable values of small flysch river water. Annual Set The Environment Protection, Vol. 16, pp. $546-561$.

10. Policht-Latawiec A., Kanownik W., Łukasik D. 2013. Effect of point source pollution on the San river water quality. Infrastructure and Ecology of Rural Areas, No 11/IV, pp. 253-269.

11. Regulation of the Minister of the Environment of November 27, 2002 on the requirements to be met by surface waters used to supply people with water intended for consumption (Journal of Laws of
2002, No. 204, item 1728).

12. Regulation of the Minister of the Environment of 19 July 2016 A on the forms and method of monitoring of surface water bodies and underground bodies (Journal of Laws of 2016, item 1178).

13. Regulation of the Minister of the Environment of July 21, 2016 B on the method of classification of the state of surface water bodies and environmental quality standards for priority substances (Journal of Laws of 2016, item 1187).

14. Report on the state of the environment in the Podkarpackie voivodship in 2016. Library of Environmental Monitoring, Rzeszów 2016. 